\title{
Syntheses in Aqueous Solution and Crystal Structure of a Triamido-Bridged Dicobalt(III) Complex with the Ligands 1,4,7-Triazacyclononane and 3-Thiapentane-1,5-diamine
}

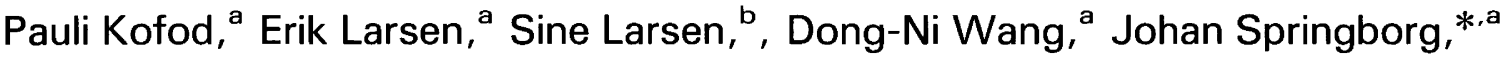 \\ and Gudrun B. Paulsen ${ }^{a}$
}

${ }^{a}$ Chemistry Department, Royal Veterinary and Agricultural University, Thorvaldsensvej 40 DK-1871 Frederiksberg C, Denmark and ${ }^{\mathrm{b}}$ Department of Chemistry, University of Copenhagen, Universitetsparken 5, DK-2100 Copenhagen $\emptyset$, Denmark

Kofod, P., Larsen, E., Larsen, S., Wang D.-N, Springborg, J. and Paulsen G. B., 1994. Syntheses in Aqueous Solution and Crystal Structure of a TriamidoBridged Dicobalt(III) Complex with the Ligands 1,4,7-Triazacyclononane and 3-Thiapentane-1,5-diamine. - Acta Chem. Scand. 48: 283-289 () Acta Chemica Scandinavica 1994.

The reaction of $\operatorname{Co}(\operatorname{tacn})(\mathrm{daes})^{3+} \quad[\operatorname{tacn}=1,4,7-$ triazacyclonane; daes $=(3-$ thiapentane-1,5-diamine $=\operatorname{di}(2$-aminoethyl $)$ sulfide $)]$ in $4 \mathrm{M} \mathrm{NaOH}$ yields nearly quantitively the triamido-bridged dicobalt(III) complex: $\mu$-1,4-diaza-7-azanidocyclononane-1 $\kappa^{2} N^{1}, N^{4}, 1: 2 \kappa^{2} N^{7}-\mu_{2}$-4-thiapentane-1,5-amido- $1 \kappa S, 1: 2 \kappa^{4} N, N^{\prime}$ - 1,4,7-triazacyclononane- $2 \kappa^{3} N^{1}, N^{4}, N^{7}$ dicobalt(III) ion, in the following abbreviated as $\operatorname{Co}(\operatorname{tacn}-\mu-N)\left(\right.$ daes $\left.-\mu_{2}-N^{1}, N^{2}\right) \operatorname{Co}(\operatorname{tacn})^{3+}$ :

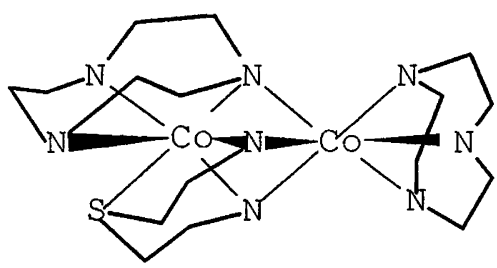

The new dinuclear cation was isolated from the reaction mixture as a perchlorate salt in high yield $(63 \%)$. The crystal and molecular structure of [Co(tacn$\mu-N)\left(\right.$ daes- $\left.\left.\mu_{2}-N^{1}, N^{2}\right) \mathrm{Co}(\operatorname{tacn})\right]\left(\mathrm{ClO}_{4}\right)_{3} \cdot \mathrm{H}_{2} \mathrm{O}$ has been established by X-ray diffraction techniques at $122 \mathrm{~K}: a=15.289(2), b=21.392(2)$ and $c=17.834(4) \AA$, $V=5228(5) \AA^{3}, F(000)=3344, Z=8$, space group $P b c a, R_{\mathrm{w}}=0.038$ for 3124 unique reflections.

\begin{abstract}
Amido-bridged transition metal complexes are well known and among the first examples are the dicobalt(III) species reported by Werner at the beginning of this century. ${ }^{1}$ They are analogues to the much more studied hydroxo-bridged species, and for many of the known amido-bridged species the corresponding hydroxobridged analogues have been reported and studied in detail. ${ }^{2}$ The kinetics and thermodynamics of the hydroxobridged species and the interconversion reactions between these have been studied for, in particular, the trivalent complexes of cobalt, chromium, rhodium and iridium and has recently been reviewed in two articles. ${ }^{2,3}$ The formation of a hydroxo-bridged species is initiated by
\end{abstract}

* To whom correspondence should be addressed. deprotonation of an aqua complex followed by the condensation of $\mathrm{M}-\mathrm{OH}$ and $\mathrm{M}-\mathrm{OH}_{2}$ species. In the same way amido-bridged ammine complexes probably occur by deprotonation of a coordinated ammonia followed by condensation of $\mathrm{M}-\mathrm{NH}_{2}$ and $\mathrm{M}-\mathrm{NH}_{3}$ species. It is now well established that the thermodynamic and kinetic properties of hydroxo-bridged complexes are strongly influenced by intramolecular hydrogen bonds between coordinated hydroxide and coordinated water. ${ }^{2-6}$ Likewise, recent studies have shown that intermolecular bonds between coordinated $\mathrm{NH}^{-}$and coordinated $\mathrm{NH}_{3}$ play a prominent role in determining the stability of the corresponding amido-bridged ammine complexes. ${ }^{7}$

Following these analogies it is not surprising that, while the hydroxo-bridged complexes often are formed by 
reactions in aqueous solvents, the amide species can be made in liquid ammonia. However, many of the classical amido-bridged compounds are obtained by reactions in aqueous solvent, but in all cases the precursor is then another bridged species. One example is the reaction of the peroxo-bridged complex $\left(\mathrm{NH}_{3}\right)_{5} \mathrm{Co}\left(\mathrm{O}_{2}\right) \mathrm{Co}\left(\mathrm{NH}_{3}\right)_{5}^{4}+$ in aqueous ammonia which gives $\left(\mathrm{NH}_{3}\right)_{4} \mathrm{Co}\left(\mathrm{NH}_{2}\right)$ $(\mathrm{OH}) \mathrm{Co}\left(\mathrm{NH}_{3}\right)_{4}^{4}+{ }^{1}$ Condensation of two monomeric cobalt(III) species to form an amido-bridged species has to our knowledge only been reported for reactions in liquid ammonia. One recent example of the latter type of reaction is the preparation of the first known triamido-bridged complex $\left(\mathrm{NH}_{3}\right)_{3} \mathrm{Co}\left(\mathrm{NH}_{2}\right)_{3} \mathrm{Co}\left(\mathrm{NH}_{3}\right)_{3}^{3}+$ made by reaction of hexamminecobalt(III) in liquid ammonia at high pressure $\left(24 \mathrm{~h}\right.$ at $\left.100^{\circ} \mathrm{C}\right){ }^{8}$ The present work reports the synthesis and single-crystal structure of a new and unexpected triamido-bridged complex, which is obtained by a reaction $\mathrm{Co}(\operatorname{tacn})(\text { daes })^{3+}$ in aqueous sodium hydroxide [ daes $=3$-thiapentane-1,5-diamine $=\operatorname{di}(2$-aminoethyl $)$ sulfide)]. To our knowledge this is the first example of formation of a substituted amido-bridged cobalt(III) species by dimerization in aqueous solution of the parent mononuclear species.

\section{Experimental}

Materials. $[\mathrm{Co}(\operatorname{tacn})($ daes $)] \mathrm{Cl}_{3} \cdot \mathrm{H}_{2} \mathrm{O}, \quad\left[(\operatorname{tacn}) \mathrm{Co}(\mathrm{OH})_{3}\right.$ $\mathrm{Co}(\operatorname{tacn})]\left(\mathrm{ClO}_{4}\right)_{3} \cdot 4 \mathrm{H}_{2} \mathrm{O}$, trans $-\left[\left(\mathrm{H}_{2} \mathrm{O}\right)(\operatorname{tacn}) \mathrm{Co}(\mathrm{OH})_{2}\right.$ $\left.\mathrm{Co}(\operatorname{tacn})\left(\mathrm{OH}_{2}\right)\right]\left(\mathrm{ClO}_{4}\right)_{4} \cdot 4 \mathrm{H}_{2} \mathrm{O}$ and $\mathrm{Co}(\operatorname{tacn}) \mathrm{Cl}_{3}$ were prepared as described previously. ${ }^{9-12}$ All other chemicals were of analytical grade.

UV-VIS absorption spectra. UV-VIS absorption were obtained using a Perkin-Elmer Lambda diode array spectrophotometer or a Cary 3 spectrophotometer.

NMR Spectra. NMR spectra were measured at $5.87 \mathrm{~T}$ on a Bruker AC 250 NMR spectrometer equipped with a $5 \mathrm{~mm}$ probe for ${ }^{13} \mathrm{C}$ NMR measurement or a $10 \mathrm{~mm}$ broad-band tunable probe for ${ }^{59} \mathrm{Co}$ NMR measurements. ${ }^{13} \mathrm{C}$ chemical shift values $(\delta)$ are reported in ppm relative to 2,2-dimethyl-2-silapentane-5-sulfonate (DSS; $\delta=0$, $17.66,21.74$ and $57.02 \mathrm{ppm}$ ). ${ }^{59} \mathrm{Co}$ chemical-shift values $(\delta)$ are reported in ppm relative to an external aqueous solution of $\mathrm{K}_{3}[\mathrm{Co}(\mathrm{CN})]_{6}(\delta=0 \mathrm{ppm})$, using replacement of the sample.

\section{Synthesis}

$\left[\mathrm{Co}(\right.$ tacn $-\mu-\mathrm{N})\left(\right.$ daes $\left.-\mu_{2}-\mathrm{N}^{l}, \mathrm{~N}^{2}\right) \mathrm{Co}($ tacn $\left.)\right]\left(\mathrm{ClO}_{4}\right)_{3} \cdot \mathrm{H}_{2} \mathrm{O}$. A solution of $[\mathrm{Co}(\operatorname{tacn})($ daes $)] \mathrm{Cl}_{3} \cdot \mathrm{H}_{2} \mathrm{O}(3.93 \mathrm{~g}, 9.08 \mathrm{mmol})$ in $4 \mathrm{M} \mathrm{NaOH}(4.9 \mathrm{ml}, 19.6 \mathrm{mmol})$ was heated in a closed Teflon tube to $60^{\circ} \mathrm{C}$ for $1 \mathrm{~h}$ and then cooled in ice. To the cold solution was then added, with stirring and cooling in ice, ice-cold water $(37 \mathrm{ml})$ and thereafter ice-cold $1 \mathrm{M} \mathrm{NH}_{4} \mathrm{ClO}_{4}(37 \mathrm{ml})$. Purple-brown crystals separated.
After $20 \mathrm{~min}$ the precipitate was filtered off, washed with one $5 \mathrm{ml}$ portion of ice-cold water, three $20 \mathrm{ml}$ portions of $96 \%$ ethanol and finally with diethyl ether and then dried in air. Yield $2.33 \mathrm{~g}(63 \%)$. IE-HPLC analysis showed that the product was pure. (Found: C 23.5; H 5.08; $\mathrm{N} 13.91 ; \mathrm{Cl} 13.35 ; \mathrm{S}$ 3.90. Calc. for $\mathrm{Co}_{2} \mathrm{C}_{16} \mathrm{H}_{41} \mathrm{~N}_{8} \mathrm{SCl}_{3} \mathrm{O}_{13}$ : C 23.7; H $5.10 ; \mathrm{N} 13.84 ; \mathrm{Cl}$ 13.13; S 3.96.). Data for the UV-VIS absorption spectrum in water are: $\left\{\varepsilon /\left[(\mathrm{M} \text { cobalt(III) })^{-1} \mathrm{~cm}^{-1}\right], \lambda /\right.$ $\mathrm{nm}\}_{\max }=(19600,212) ;(153,550)$ and $\{\varepsilon /[(\mathrm{M}$ cobal$\left.\left.\mathrm{t}(\mathrm{III}))^{-1} \quad \mathrm{~cm}^{-1}\right], \lambda / \mathrm{nm}\right\}_{\mathrm{sh}}=(389,400) ;(15800,239) \quad(\mathrm{see}$ also Fig. 1). The ${ }^{1} \mathrm{H}$ decoupled ${ }^{13} \mathrm{C}$ NMR spectrum of a solution of the perchlorate salt in $\mathrm{D}_{2} \mathrm{O}(300 \mathrm{~K})$ showed the following eight singlets: $\delta 42.6,51.1,51.9,52.2,52.3$, 53.9, 55.2, 61.5 .

Crystals of the triamido-bridged complex, suitable for $\mathrm{X}$-ray structure analysis, were obtained from the reaction of $\mathrm{Co}(\operatorname{tacn})(\text { daes })^{3+}$ and base. A $0.6 \mathrm{M}$ solution of $[\mathrm{Co}(\operatorname{tacn})($ daes $)] \mathrm{Cl}_{3} \cdot \mathrm{H}_{2} \mathrm{O}$ in $2 \mathrm{M} \mathrm{NaOH}$ was kept $90 \mathrm{~min}$ at $59^{\circ} \mathrm{C}$, cooled in ice and then added one volume of a saturated solution of $\mathrm{NaClO}_{4}$ with a minimum of mixing of the two solvents. The mixture was kept at $5^{\circ} \mathrm{C}$ for $24 \mathrm{~h}$. A mixture of red and yellow and purple-brown crystals separated. The red and yellow crystals were identified by IE-HPLC as salts of $\mathrm{Co}(\operatorname{tacn})(\text { daes })^{3+}$ and $(\operatorname{tacn}) \mathrm{CO}(\mathrm{OH})_{3} \mathrm{Co}(\operatorname{tacn})^{3+}$, respectively. The purplebrown crystals were shown by IE-HPLC to be identical with the perchlorate salt described above and were identified as the triamido-bridged species by a crystal structure analysis as described below.

IE-HPLC measurements. Ion-exchange high-performance liquid chromatography (IE-HPLC) was performed using waters IE-HPLC system connected to a diode array detector. A Waters Protein Pak SP-5PW cation-exchanger was used and $0.23 \mathrm{M} \mathrm{Na}_{2} \mathrm{SO}_{4}$ was used as eluent in all experiments and the volumes of retention $\left(V_{\mathrm{r}}\right)$ given all refer to a flow of $1.0 \mathrm{ml} \mathrm{min}^{-1}$. The IE-HPLC experiments were made at 0 and $25^{\circ} \mathrm{C}$. All basic solutions were cooled in ice, diluted with cold water and then neutralized

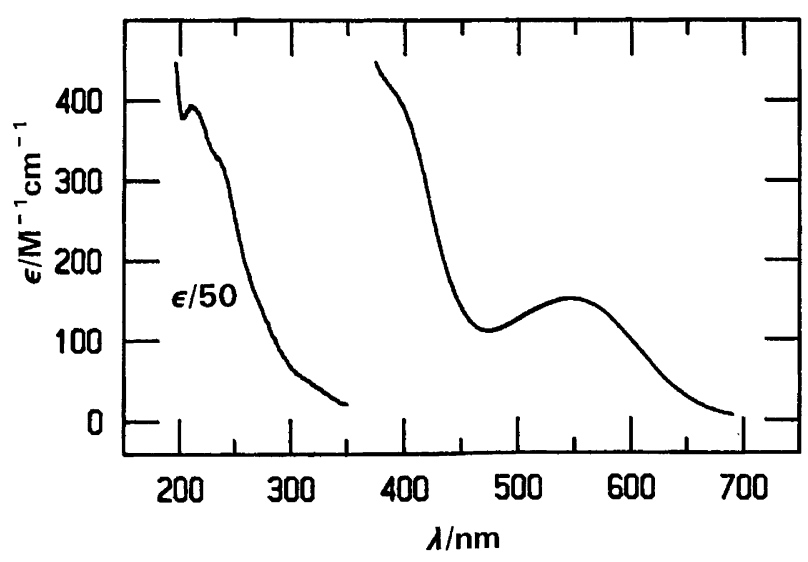

Fig. 1. Absorption spectrum of [Co(tacn- $\mu-N)\left(\right.$ daes $-\mu_{2}-$ $\left.N^{1}, N^{2}\right) \mathrm{Co}($ tacn $\left.)\right]\left(\mathrm{ClO}_{4}\right)_{3} \cdot \mathrm{H}_{2} \mathrm{O}$ in water at $25^{\circ} \mathrm{C}$. 
by addition of excess cold $1 \mathrm{M}$ ammonium chloride prior to the IE-HPLC analysis. Solutions of pure $\mathrm{Co}(\mathrm{tac}-$ $\mathrm{n})(\mathrm{OH})_{3}$ were made by dissolving $\mathrm{Co}(\operatorname{tacn}) \mathrm{Cl}_{3}$ in $1 \mathrm{M}$ $\mathrm{NaOH}$. The hydrolysis is complete within minutes at room temperature. The purity was controlled by IEHPLC analyses. The concentrations of the cobalt(III) species in the product solutions (Fig. 2) were determined from chromatograms measured at $246 \mathrm{~nm}$. At this wavelength the species $\mathrm{Co}(\operatorname{tacn})(\text { daes })^{3+}, \mathrm{Co}(\operatorname{tacn})(\mathrm{OH})_{3}$, $(\operatorname{tacn}) \mathrm{Co}(\mathrm{OH})_{3} \mathrm{Co}(\operatorname{tacn})^{3+}$ and $\mathrm{Co}(\operatorname{tacn}-\mu-N)\left(\right.$ daes- $\mu_{2-}$ $\left.N^{1}, N^{2}\right) \mathrm{Co}(\operatorname{tacn})^{3+}$ have similar and high molar absorption coefficients: $10300,9062,7825$ and $14400 \mathrm{M}^{-1}$ $\mathrm{cm}^{-1}$, respectively [molarity with respect to Co(III)]. The concentrations of the individual species were then calculated using these values and the integrated chromatograms as described previously. ${ }^{13}$

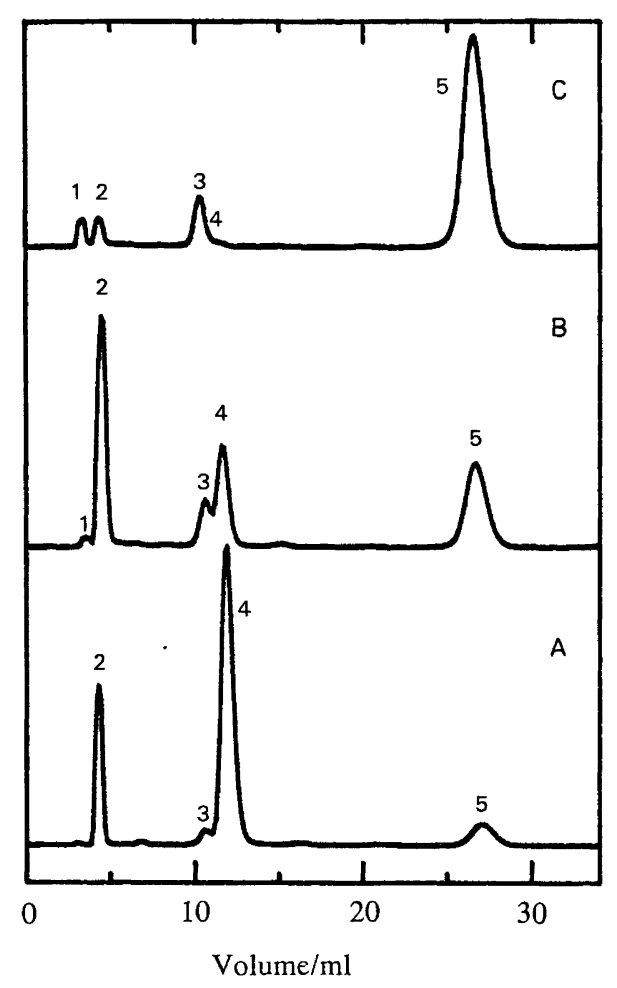

Fig. 2. IE-HPLC chromatograms for the equilibrium solutions obtained from the reaction of $1.6 \mathrm{M} \mathrm{Co}\left(\right.$ tacn) $(\text { daes })^{3+}$ in 1-4 $\mathrm{M} \mathrm{NaOH}$ at $59^{\circ} \mathrm{C}$ (monitored using $\lambda=246 \mathrm{~nm}$ at $25^{\circ} \mathrm{C}$ ). Curves $A, B$ and $C$, respectively, are for $[\mathrm{NaOH}]=1.0$, 2.0 and $4.0 \mathrm{M} \mathrm{NaOH}$; the concentrations of hydroxide in the equilibrium solutions can be calculated from the stoichiometry and are $0.23,0.29$ and $1.8 \mathrm{M}$, respectively. The peaks $1,2,4$ and 5 , respectively, were identified as Co(tacn) $(\mathrm{OH})_{3},($ tacn $) \mathrm{Co}(\mathrm{OH})_{3} \mathrm{Co}(\mathrm{tacn})^{3+}, \mathrm{Co}(\operatorname{tacn})(\text { daes })^{3+}$ and Coltacn- $\mu-N)\left(\right.$ daes $\left.-\mu_{2}-N^{1}, N^{2}\right)$ Co $(\text { tacn })^{3+}\left(V_{r}=3.2,4.5,12.4\right.$ and $27 \mathrm{ml}$, respectively). The peak $3\left(V_{\mathrm{r}}=10.2 \mathrm{ml}\right)$ was not identified. A minor tail following the peak for $($ tacn $) \mathrm{Co}(\mathrm{OH})_{3} \mathrm{Co}(\mathrm{tacn})^{3+}$ was identified as trans$\left(\mathrm{H}_{2} \mathrm{O}\right)(\operatorname{tacn}) \mathrm{Co}(\mathrm{OH})_{2} \mathrm{Co}(\operatorname{tacn})\left(\mathrm{H}_{2} \mathrm{O}\right)^{4+}$.
Crystal structure. A CAD4 diffractometer equipped with an Enraf-Nonius gas-flow temperature device was used for the data collection. The temperature was monitored with a thermocouple placed a few centimeters above the crystal in the exhaust pipe. Graphite monochromatized Mo $K \alpha$ radiation was employed. Data reduction included corrections for Lorentz polarization and absorption effects. Transmission factors were in the range $0.653-0.900$. The crystal data and a summary of data collection parameters and refinement results are listed in Table 1. The crystallographic computations were performed with the SDP system. ${ }^{14}$ The space group was determined using Weissenberg photographs. [Co(tacn- $\mu$ $N)\left(\right.$ daes- $\left.\left.\mu_{2}-N^{1}, N^{2}\right) \mathrm{Co}(\operatorname{tacn})\right]\left(\mathrm{ClO}_{4}\right)_{3} \cdot \mathrm{H}_{2} \mathrm{O}$ belongs to the orthorhombic system, and the systematically absent reflections determine the space group as $P b c a$.

The structure was solved by a combination of Patterson and direct methods (SHELXS-86) ${ }^{15}$ The refinement was made by full-matrix least-squares minimizing of $\Sigma w\left(\left|F_{\mathrm{o}}\right|-\left|F_{\mathrm{c}}\right|\right)^{2}$. The positions of the hydrogen atoms were revealed in the difference Fourier calculated after an anisotropic refinement. Calculated positions and a fixed thermal parameter of $2.5 \AA^{2}$ were used for the final refinement. The final heavy-atom positional parameters are given in Table 2 .

\section{Results and discussion}

Synthesis and properties of the triamido-bridged dicobalt(III) species. Recently we reported ${ }^{12}$ a kinetic study of the base hydrolysis of $\mathrm{Co}(\operatorname{tacn})(\mathrm{daes})^{3+}$. It was shown that in $1 \mathrm{M} \mathrm{NaOH}$ the dominant reactions for $[\mathrm{Co}]_{\text {total }}=$ $0.002-0.05 \mathrm{M}$ are formation of $\mathrm{Co}(\operatorname{tacn})(\mathrm{OH})_{3}$ [dominant at lower cobalt(III) concentrations] and of $(\operatorname{tacn}) \mathrm{Co}(\mathrm{OH})_{3} \mathrm{Co}(\operatorname{tacn})^{3+}$ [dominant at higher cobal$t($ III) concentrations] as shown in eqns. (1) and (2).

$$
\mathrm{Co}(\operatorname{tacn})(\text { daes })^{3+}+3 \mathrm{HO}^{-} \stackrel{K_{\mathrm{h}}}{\rightleftarrows} \mathrm{Co}(\operatorname{tacn})(\mathrm{OH})_{3}+\text { daes }
$$

$$
2 \mathrm{Co}(\operatorname{tacn})(\mathrm{OH})_{3} \stackrel{K_{\text {triol }}}{\rightleftarrows}(\operatorname{tacn}) \mathrm{Co}(\mathrm{OH})_{3} \mathrm{Co}(\mathrm{tacn})^{3+}+
$$

In strong base the $\mathrm{Co}(\operatorname{tacn})(\text { daes })^{3+}$ species deprotonates, $\mathrm{p} K_{\mathrm{a}}=13.44$, probably at one of the coordinated amine groups of the tacn ligand. ${ }^{9}$ It is also possible that the other species in eqns. (1) and (2) deprotonate to corresponding amido complexes. For the sake of simplicity these equilibria were ignored in Ref. 12, and are also ignored in the discussion here. Likewise, possible ${ }^{2}$ deprotonations of the hydroxo-bridges to form hydroxo-oxobridged species were ignored. The following equilibrium constants were reported: $K_{\mathrm{h}}=0.78(20) \quad \mathrm{M}^{-2}$ and $K_{\text {triol }}=17(3) \mathrm{M}^{2}$.

In the present work we have studied the reactions for solutions with very large cobalt(III) concentrations 
Table 1. Crystal data and a summary of data reduction and structure refinement.

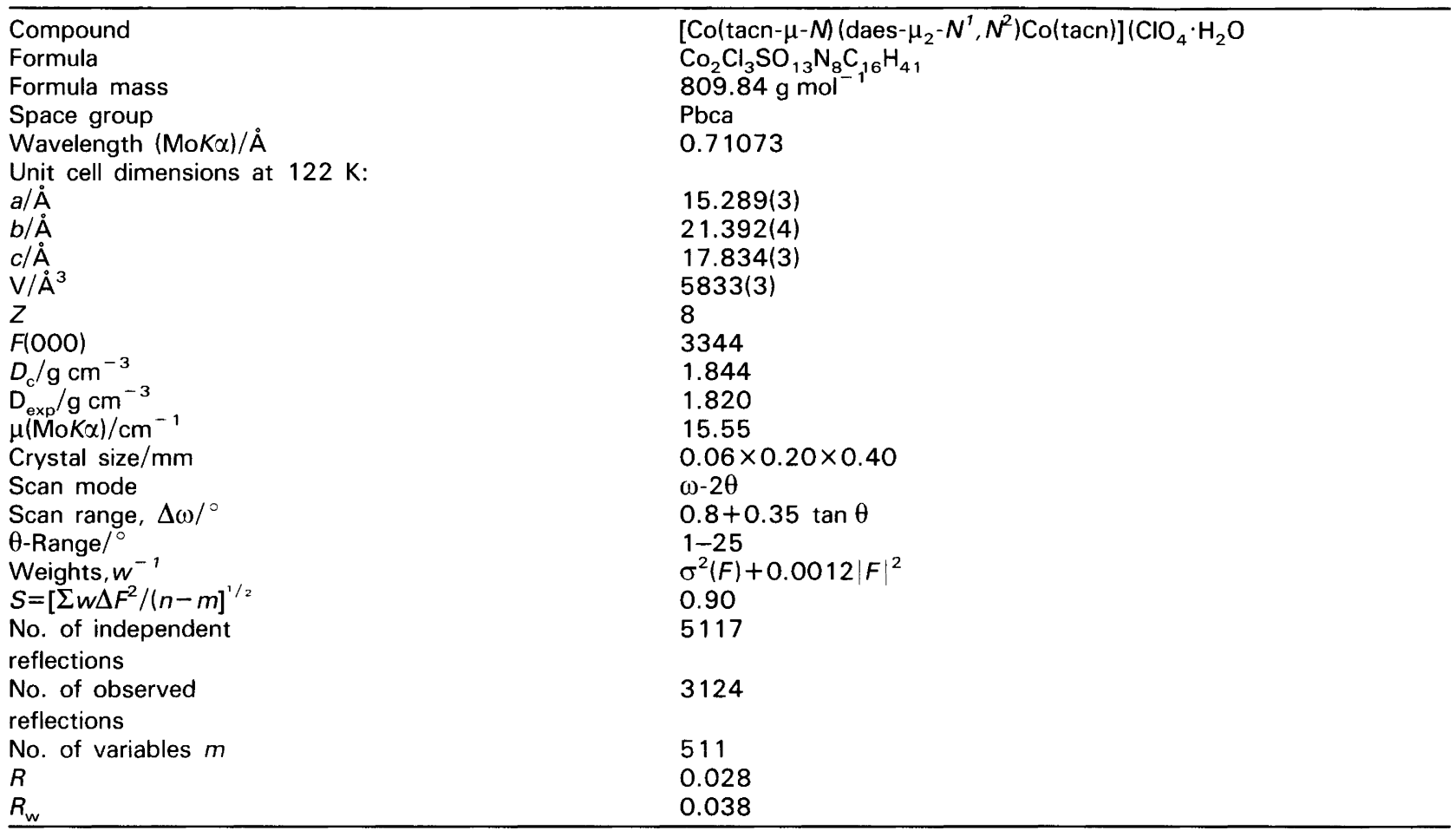

(1.6 M) and with high base concentrations: 1-4 M $\mathrm{NaOH}$. The reactions were performed at $59^{\circ} \mathrm{C}$, and the product distribution was determined by IE-HPLC analysis. For each base concentration it was shown that heating for 1 and $2 \mathrm{~h}$, respectively, gave the same result, and it is therefore assumed that equilibrium has been attained. The chromatograms in Fig. 2 illustrate how the equilibrium concentrations of the different species vary with the base concentration. First it is noted that up to five dominant species are present: the three species already known: $\left[\mathrm{Co}(\operatorname{tacn})(\mathrm{OH})_{3}\left(V_{\mathrm{r}}=3.2 \mathrm{ml}\right),(\mathrm{tacn}) \mathrm{Co}(\mathrm{OH})_{3} \mathrm{Co}(\mathrm{tacn})^{3+}\right.$ $\left(V_{\mathrm{r}}=4.5 \mathrm{ml}\right)$ and $\left.\operatorname{Co}(\mathrm{tacn})(\text { daes })^{3+}\left(V_{\mathrm{r}}=12.4 \mathrm{ml}\right)\right]$ and two new species with $V_{\mathrm{r}}=10.2$ and $27 \mathrm{ml}$. The known species were identified by comparison of their volumes of retention $\left(V_{\mathrm{r}}\right)$ and their UV-VIS spectra with those of the authentic species. The species which has $V_{\mathrm{r}}=10.2 \mathrm{ml}$ was not identified. The other new cation has a volume of retention $\left(V_{\mathrm{r}}=27 \mathrm{ml}\right)$, which indicates that it is an oligomer. In Fig. 2 it is shown how the concentration of this new cation increases when the concentration of base increases and that it is formed nearly quantitatively in $4 \mathrm{M} \mathrm{NaOH}\left(\left[\mathrm{OH}^{-}\right]=1.8 \mathrm{M}\right.$ at equilibrium). The new species was isolated from the reaction of $1.9 \mathrm{M}$ $[\mathrm{Co}($ tacn $)($ daes $)] \mathrm{Cl}_{3} \cdot \mathrm{H}_{2} \mathrm{O}$ in $4 \mathrm{M} \mathrm{NaOH}$ as a purplebrown perchlorate salt in $63 \%$ yield. A single-crystal $\mathrm{X}$-ray structure analysis has shown (see below) that the product is a dinuclear triamido-bridged cation formed by the condensation of $\mathrm{Co}(\operatorname{tacn})(\mathrm{OH})_{3}$ with $\mathrm{Co}(\operatorname{tacn})(\mathrm{daes})^{3+}$ as shown in eqn. (3) (see also Figs. 3 and 4).
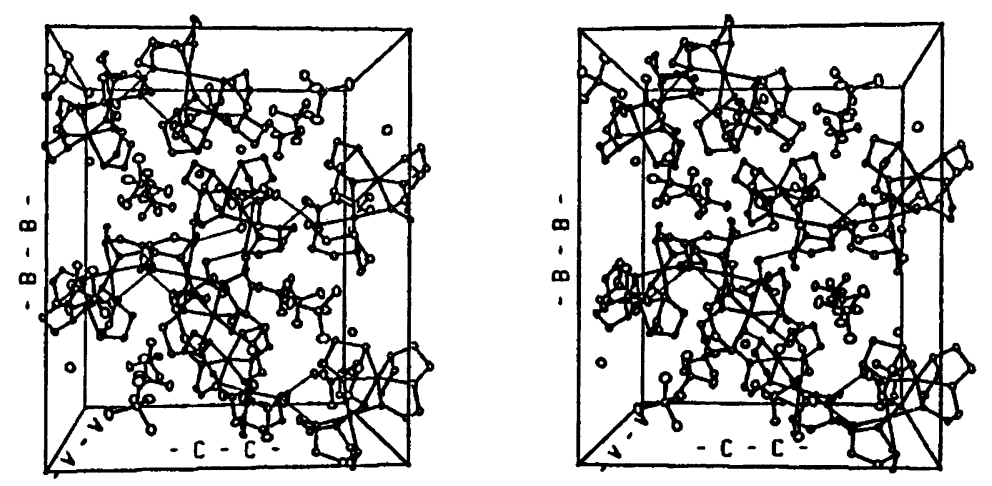

Fig. 3. Stereoscopic picture of the unit cell along the a-axis. 
Table 2. Fractional coordinates and the equivalent isotropic temperature factors for atoms in [Coltacn- $\mu-N)$ (daes- $\mu_{2}-$ $\left.N^{1}, N^{2}\right) \mathrm{Co}($ tacn $\left.)\right]\left(\mathrm{ClO}_{4}\right)_{3} \cdot \mathrm{H}_{2} \mathrm{O}^{\mathrm{a}}$

\begin{tabular}{|c|c|c|c|c|}
\hline Atom & $x / a$ & $y / b$ & $z / c$ & $B_{\text {iso }} / \AA^{3 b}$ \\
\hline Co 1 & $0.75079(3)$ & $0.33071(2)$ & $0.03459(3)$ & $1.249(9)$ \\
\hline $\mathrm{Co} 2$ & $0.78070(3)$ & $0.42919(2)$ & $0.11424(3)$ & $1.152(9)$ \\
\hline N11 & $0.6829(2)$ & $0.3377(2)$ & $-0.0596(2)$ & $1.77(6)$ \\
\hline N12 & $0.8374(2)$ & $0.2852(2)$ & $-0.0261(2)$ & $1.81(7)$ \\
\hline N13 & $0.8085(2)$ & $0.4066(1)$ & $0.0076(2)$ & $1.48(6)$ \\
\hline C11 & $0.7247(3)$ & $0.2997(2)$ & $-0.1205(2)$ & $2.64(9)$ \\
\hline C12 & $0.7879(3)$ & $0.2543(2)$ & $-0.0875(2)$ & $2.54(9)$ \\
\hline C13 & $0.6798(3)$ & $0.4058(2)$ & $-0.0777(2)$ & $1.91(8)$ \\
\hline C14 & $0.7683(3)$ & $0.4346(2)$ & $-0.0604(2)$ & $1.79(8)$ \\
\hline C15 & $0.9015(3)$ & $0.3896(2)$ & $-0.0100(2)$ & $1.83(8)$ \\
\hline C16 & $0.9047(3)$ & $0.3302(2)$ & $-0.0550(2)$ & $2.10(8)$ \\
\hline $\mathrm{S}$ & $0.68532(7)$ & $0.24636(5)$ & $0.08395(6)$ & $1.85(2)$ \\
\hline N11d & $0.8196(2)$ & $0.3413(1)$ & $0.1252(2)$ & $1.29(6)$ \\
\hline N12d & $0.6737(2)$ & $0.3849(1)$ & $0.0900(2)$ & $1.31(6)$ \\
\hline C11d & $0.7602(3)$ & $0.2364(2)$ & $0.1627(2)$ & $2.02(8)$ \\
\hline C12d & $0.5909(3)$ & $0.2874(2)$ & $0.1224(3)$ & $2.45(9)$ \\
\hline C 13d & $0.7993(3)$ & $0.2988(2)$ & $0.1895(2)$ & $1.87(8)$ \\
\hline C14d & $0.6154(3)$ & $0.3541(2)$ & $0.1472(2)$ & $2.13(8)$ \\
\hline N21 & $0.7335(2)$ & $0.5133(1)$ & $0.0955(2)$ & $1.44(6)$ \\
\hline N22 & $0.8919(2)$ & $0.4728(2)$ & $0.1352(2)$ & $1.61(6)$ \\
\hline N23 & $0.7544(2)$ & $0.4464(1)$ & $0.2201(2)$ & $1.42(6)$ \\
\hline C21 & $0.8038(3)$ & $0.5613(2)$ & $0.057(2)$ & $2.09(8)$ \\
\hline $\mathrm{C} 22$ & $0.8917(3)$ & $0.5305(2)$ & $0.0888(2)$ & $2.11(8)$ \\
\hline$C 23$ & $0.6652(3)$ & $0.5240(2)$ & $0.1541(2)$ & $2.20(8)$ \\
\hline$C 24$ & $0.7031(3)$ & $0.5055(2)$ & $0.2283(2)$ & $1.99(8)$ \\
\hline C25 & $0.8397(3)$ & $0.4465(2)$ & $0.2603(2)$ & $2.12(8)$ \\
\hline $\mathrm{C} 26$ & $0.9020(3)$ & $0.4864(2)$ & $0.2174(2)$ & 2. $10(8)$ \\
\hline $\mathrm{Cl} 1$ & $1.10259(6)$ & $0.38055(4)$ & $0.11929(5)$ & $1.75(2)$ \\
\hline 011 & $1.0890(2)$ & $0.4469(1)$ & $0.1155(2)$ & $3.04(7)$ \\
\hline 012 & $1.1103(2)$ & $0.3556(2)$ & $0.0457(2)$ & $2.71(6)$ \\
\hline 013 & $1.0273(2)$ & $0.3530(2)$ & $1.554(2)$ & $2.90(7)$ \\
\hline 014 & $1.1793(2)$ & $0.3665(2)$ & $0.1620(2)$ & $2.78(6)$ \\
\hline $\mathrm{Cl} 2$ & $0.59149(6)$ & $0.60564(5)$ & $-0.03183(6)$ & $1.96(2)$ \\
\hline 021 & $0.5920(2)$ & $0.6375(1)$ & $-0.1028(2)$ & $2.63(6)$ \\
\hline $\mathrm{O} 22$ & $0.6409(2)$ & $0.6413(1)$ & $0.0226(2)$ & $2.47(6)$ \\
\hline $\mathrm{O} 23$ & $0.5037(2)$ & $0.5986(2)$ & $-0.0060(2)$ & $2.96(7)$ \\
\hline 024 & $0.6215(2)$ & $0.5453(1)$ & $-0.0407(2)$ & $3.16(7)$ \\
\hline $\mathrm{Cl} 3$ & $1.00391(7)$ & $0.64572(4)$ & $0.25399(6)$ & $1.99(2)$ \\
\hline 031 & $1.0525(2)$ & $0.5996(2)$ & $0.2131(2)$ & $2.98(7)$ \\
\hline 032 & $0.9174(2)$ & $0.6489(1)$ & $0.2244(2)$ & $2.58(8)$ \\
\hline 033 & $0.9989(2)$ & $0.6274(2)$ & $0.3306(2)$ & $3.70(8)$ \\
\hline 034 & $1.0445(2)$ & $0.7053(2)$ & 0.246821 & $4.15(8)$ \\
\hline Ow & $0.5006(2)$ & $0.2335(1)$ & $0.4361(2)$ & $3.32(7)$ \\
\hline
\end{tabular}

a The cobalt atoms are numbered 1 and 2 . To Co 1 is bound the tacn ligand 1, where $\mathrm{N} 11$ and $\mathrm{N} 12$ coordinate in a usual fashion while the deprotonated $\mathrm{N} 13$ forms a bridge to $\mathrm{Co} 2$. The daes ligand coordinates to $\mathrm{Co} 1$ with the thioether sulfur atom, while the deprotonated $\mathrm{N} 11 \mathrm{~d}$ and $\mathrm{N} 12 \mathrm{~d}$ form bridges between $\mathrm{Co} 1$ and $\mathrm{Co} 2$. The second tacn ligand occupies the remaining face of $\mathrm{Co} 2$.

$$
\begin{aligned}
& { }^{\mathrm{b}} B_{\text {iso }}=\frac{8 \pi^{2}}{3} \sum_{i} \sum_{j} U_{i j} a_{i} a_{j} a^{*} a^{*}{ }^{*}{ }^{*} \\
& C o(\text { tacn })(\text { daes })^{3+}+\mathrm{Co}(\operatorname{tacn})(\mathrm{OH})_{3} \stackrel{K_{\text {amido }}}{\rightarrow} \\
& \operatorname{Co}(\text { tacn }-\mu-N)\left(\text { daes }-\mu_{2}-N^{1}, N^{2}\right) \mathrm{Co}(\text { tacn })^{3+}+3 \mathrm{H}_{2} \mathrm{O}
\end{aligned}
$$

The new triamido-bridged species is stable for several hours in aqueous basic, neutral or acidic solution $\left(25^{\circ} \mathrm{C}\right.$, $\mathrm{pH} 2-12$ ) as shown spectrophotometrically. Likewise it was shown that it does not exhibit any acid-base prop- erties in the $\mathrm{pH}$ region 2-12. The UV-VIS absorption spectrum is shown in Fig. 1.

It is not easy to rationalize the observation that the concentration of the new triamido-bridged species increases with increasing base concentration. In terms of eqns. (1)-(3) it was anticipated that the monomeric Co$(\operatorname{tacn})(\mathrm{OH})_{3}$ would be dominant at very large hydroxide concentration, which clearly is not the case. The reasons are probably a radical change in the concentration equilibrium constants with the ionic strength combined with a decrease in the water activity with the increasing salt concentration. It is noted that a low water activity will stabilize the triamido-bridged species relative to Co$(\operatorname{tacn})(\mathrm{OH})_{3}$ as well as to $(\operatorname{tacn}) \mathrm{Co}(\mathrm{OH})_{3} \mathrm{Co}(\operatorname{tacn})^{3+}$. The effect of ionic strength may be illustrated by the value of the concentration equilibrium constant $K_{\text {triol, }}$, which previously was determined ${ }^{12}$ as $K_{\mathrm{d}}=17 \mathrm{M}^{-2}$ in $1 \mathrm{M} \mathrm{NaOH}$ ([Co] $=0.05 \mathrm{M})$, whereas in this work it is estimated that $K_{\text {triol }}=70 \mathrm{M}^{-2}$ in $4 \mathrm{M} \mathrm{NaOH}([\mathrm{Co}]=1.6 \mathrm{M})$. A similar, but more pronounced, change is observed for the concentration equilibrium constant $K_{\text {amido, }}$, which has the values $K_{\text {amido }}<10 \mathrm{M}^{-1}$ in $1 \mathrm{M} \mathrm{NaOH}([\mathrm{Co}]=0.05 \mathrm{M})$ and $K_{\text {amido }} \approx 10^{3} \mathrm{M}^{-1}$ in $4 \mathrm{M} \mathrm{NaOH}([\mathrm{Co}]=1.6 \mathrm{M})$. The former value for $K_{\text {amido }}$ is based upon data from Ref. 12 (all values for $59^{\circ} \mathrm{C}$ ).

Preliminary experiments indicate that a mixture Co$(\operatorname{tacn})(\mathrm{OH})_{3}$ and $\mathrm{Co}(\mathrm{en})^{3+}{ }_{3}$ in $4 \mathrm{M} \mathrm{NaOH}$ does not form an amido-bridged species. This difference in behaviour of $\mathrm{Co}(\operatorname{tacn})(\mathrm{daes})^{3+}$ and $\mathrm{Co}(\mathrm{en})^{3+}{ }_{3}$ is probably due to the different acid strength of the coordinated amine groups of the ligands 1,4,7-triazacyclononane $\left(\mathrm{p} K_{\mathrm{a}}=13.44\right)^{9}$ and 1,2-ethanediamine $\left(\mathrm{p} K_{\mathrm{a}}>14\right) .{ }^{16}$ Following these lines we propose that the first step in the formation of the present amido complex is deprotonation of an coordinated amine group of tacn in $\mathrm{Co}(\operatorname{tacn})(\mathrm{daes})^{3+}$ followed by a nucleophilic attack at the cobalt(III) center of $\mathrm{Co}(\operatorname{tacn})(\mathrm{OH})_{3}$. The subsequent steps involve deprotonation of the amine

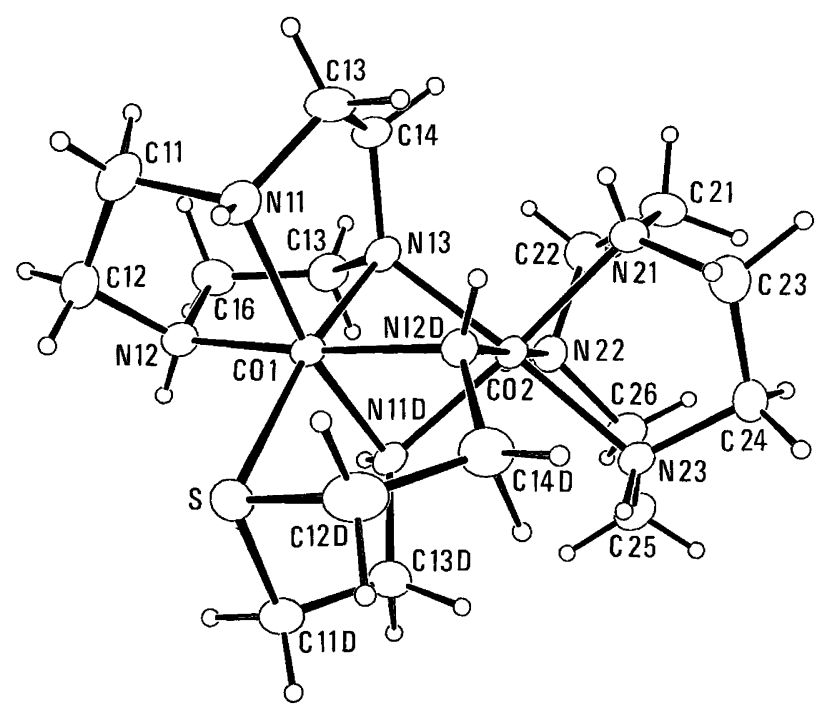

Fig. 4. ORTEP drawing of the dinuclear cation. 
KOFOD ET AL.

groups of the daes ligand; these amine groups are probably much less acidic than those of tacn, but proximity effects are likely to promote the subsequent intramolecular amido-bridge formation reactions.
${ }^{13} \mathrm{C}$ NMR Spectra. The ${ }^{13} \mathrm{C}$ NMR spectrum of a solution of $\left[\mathrm{Co}(\operatorname{tacn}-\mu-N)\left(\right.\right.$ daes- $\left.\left.\mu_{2}-N^{1}, N^{2}\right) \mathrm{Co}(\operatorname{tacn})\right]\left(\mathrm{ClO}_{4}\right)_{3} \cdot \mathrm{H}_{2} \mathrm{O}$ in $\mathrm{D}_{2} \mathrm{O}$ has eight signals (see Experimental), which shows that the cation, as expected, contains a plane of

Table 3. Selected bond lengths, $d$, and angles, $\alpha$, for $\left[\mathrm{Co}(\right.$ tacn $-\mu-N)\left(\right.$ daes $\left.-\mu_{2}-N^{1}, N^{2}\right)$ Coltacn) $]\left(\mathrm{ClO}_{4}\right)_{3} \cdot \mathrm{H}_{2} \mathrm{O}$. For labelling of the atoms consult Table 2 .

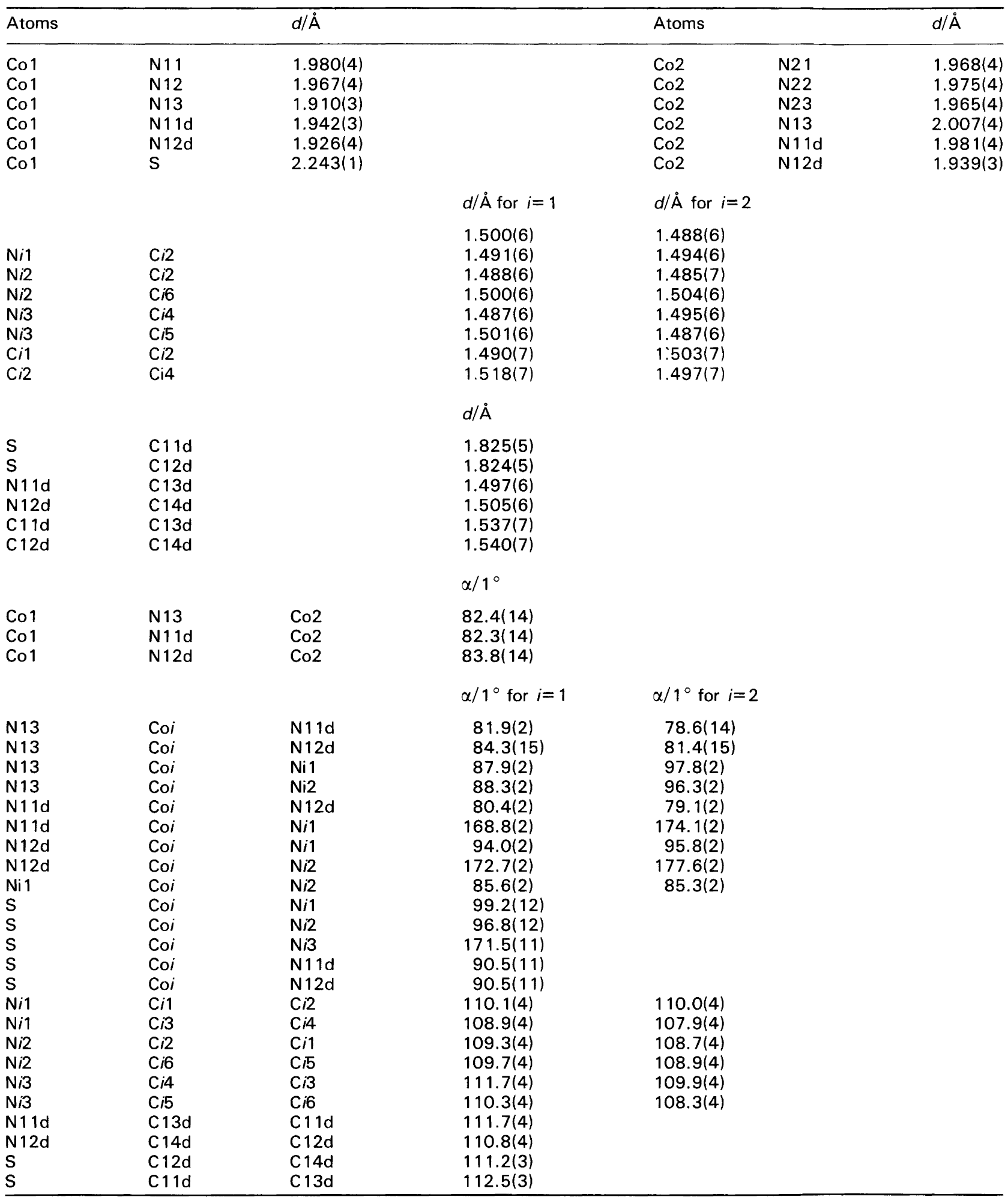


symmetry. It has not been possible to make any firm assignments of the signals, as all carbon atoms are bonded to amino groups, except $\mathrm{C} 11 \mathrm{~d}$ and $\mathrm{C} 12 \mathrm{~d}$, which are bonded to the thioether sulfur atom and presumably have the lowest resonance frequency. No exchange of deuterium for hydrogen at $\mathrm{C} 11 \mathrm{~d}$ and $\mathrm{C} 12 \mathrm{~d}$ was observed after two weeks in $1 \mathrm{M} \mathrm{NaOD}$ at $25^{\circ} \mathrm{C}$. This is in marked contrast to the rapid deuterium exchange in $\operatorname{Co}(\operatorname{tacn})(\text { aeaps })^{3+}$ at similar conditions $\left(t_{1 / 2}=\right.$ $2 \mathrm{~min}){ }^{17}$ The difference is probably mainly due to the lower charge per cobalt atom in the $\operatorname{Co}(\operatorname{tacn}-\mu-N)$ (daes$\left.\mu_{2}-N^{1}, N^{2}\right) \operatorname{Co}(\operatorname{tacn})^{3+}$ species.

A solution of $\left[\mathrm{Co}(\operatorname{tacn}-\mu-N)\left(\right.\right.$ daes $\left.\left.-\mu_{2}-N^{1}, N^{2}\right) \operatorname{Co}(\operatorname{tacn})\right]$ $\left(\mathrm{ClO}_{4}\right)_{3} \cdot \mathrm{H}_{2} \mathrm{O}$ in $\mathrm{D}_{2} \mathrm{O}$ gives two ${ }^{59} \mathrm{Co} \mathrm{NMR}$ signals at $300 \mathrm{~K}$. One is found at $\delta=5270 \mathrm{ppm}\left(\Delta v_{1 / 2}=730 \mathrm{~Hz}\right)$, the other is found at $\delta=7870 \mathrm{ppm}\left(\Delta v_{1 / 2}=3140 \mathrm{~Hz}\right)$. For comparison $\mathrm{Co}(\operatorname{tacn})(\text { daes })^{2+}$ gives a signal at $\delta=5980 \mathrm{ppm}\left(\Delta v_{1 / 2}=810 \mathrm{~Hz}\right)$, while cobalt(III) compounds with six amine ligands typically resonate in the range $7200-8200 \mathrm{ppm}^{18}$ Hence the signal at $5270 \mathrm{ppm}$ in $\mathrm{Co}(\operatorname{tacn}-\mu-N)\left(\right.$ daes $\left.-\mu_{2}-N^{1}, N^{2}\right) \operatorname{Co}(\operatorname{tacn})^{3+}$ is assigned to $\mathrm{Co} 1$ and that at $7870 \mathrm{ppm}$ is assigned to $\mathrm{Co} 2$. (Co1 and $\mathrm{Co} 2$ are defined as shown in Fig. 4.)

Description of the crystal structure. The bond distances and bond angles for the dinuclear cation $[\mathrm{Co}(\operatorname{tacn}-\mu-N)$ (daes$\left.\left.\mu_{2}-N^{1}, N^{2}\right) \mathrm{Co}(\operatorname{tacn})\right]\left(\mathrm{ClO}_{4}\right)_{3} \cdot \mathrm{H}_{2} \mathrm{O}$ are given in Table 3 . The crystal is held together by hydrogen bonding and electrostatic attractions, as may be seen from Fig. 3. The cation shown in Fig. 4 has $\mathrm{Co}-\mathrm{N}$ bond lengths varying between 1.910(3) and 2.007(4) $\AA$. The two bridging $\mathrm{NH}^{-}$ groups from daes have relatively short bond distances of $1.942(3)$ and $1.926(4) \AA$ to Co1, while Co2 has two rather different bond distances of 1.981(4) and 1.939(3) $\AA$ to the two bridging $\mathrm{NH}^{-}$groups. This unsymmetrical binding is unexpected, since the trans ligands all are tacn amino groups. The bridging $\mathrm{N}^{-}$group of tacn is also unsymmetrically binding, with a short $\mathrm{Co}-\mathrm{N}$ distance of 1.910 (3) $\AA$ to $\mathrm{Co} 1$ and a long distance of 2.007(4) $\AA$ to $\mathrm{Co} 2$. In this case the trans ligands are $\mathrm{N}$ and $\mathrm{S}$, respectively, but a coordinating thioether has been found to have little effect on the bond distance of a trans coordinating ligand, 9,19 and therefore does not explain the unsymmetrical binding. The unsymmetrical structure of the cation is therefore attributed to crystal packing forces. This is in keeping with the ${ }^{13} \mathrm{C}$ NMR data, which show that the dinuclear cation in solution possesses the expected plane of symmetry. The Co-Co distance is $2.5816(8) \AA$, and this is surprisingly similar to the distance 2.565(1) $\AA$ found for $\left(\mathrm{NH}_{3}\right)_{3} \mathrm{Co}(\mathrm{OH})_{3}$ $\mathrm{Co}\left(\mathrm{NH}_{3}\right)_{3}^{3}+$ and $2.549(8)$ found for $(\operatorname{tacn}) \mathrm{Co}(\mathrm{OH})_{3}$ $\mathrm{Co}(\operatorname{tacn})^{3+} .9,20$

Acknowledgement. Financial support from the Carlsberg Foundation and the Danish Natural Science Research Council is gratefully acknowledged. Mia B. Christensen and Anette Nielsen are thanked for assistance with the IE-HPLC experiments, and Mr. F. Hansen for help during the crystallographic data collection.

\section{References}

1. Sykes, A. G. and Weil, J. A. Progr. Inorg. Chem. 13 (1970) 1.

2. Springborg, J. In: Sykes, A. G., Ed., Advances in Inorganic Chemistry, Academic Press, San Diego 1988, Vol. 32, p. 55.

3. Andersen, P. Coord. Chem. Rev. 94 (1989) 47.

4. Galsbøl, F., Simonsen, K. and Springborg, J. Acta Chem. Scand. 46 (1992) 915.

5. Springborg, J. Acta Chem. Scand. 46 (1992) 1047.

6. Galsbøl, G., Larsen, S., Rasmussen, B. and Springborg, J. Inorg. Chem. 25 (1986) 290.

7. Heck, L., Ardon, M., Bino, A. and Zapp, J. J. Am. Chem. Soc. 110 (1988) 2691.

8. Frank, W., Hoffmann, K. and Heck, L. Angew. Chem., Int. Ed. Engl. 29 (1990) 1158.

9. Kofod, P., Larsen, E., Larsen, S., Pedersen, C. H., Springborg, J. and Wang, D.-N. Acta Chem. Scand. 46 (1992) 841.

10. Wieghardt, K., Schmidt, W., Nuber, B. and Weiss, J. Chem. Ber. 112 (1979) 2220.

11. Okamoto, M. S. and Barefield, E. K. Inorg. Chim. Acta 17 (1976) 91.

12. Larsen, E., Larsen, S., Springborg, J., Paulsen, G. B., Wang, D.-N. Acta Chem. Scand. 48 (1994) In press.

13. Bjerrum, M. J., Kaas, K., Larsen, E., Nielsen, B. and Springborg, J. Inorg. Chem. 28 (1989) 532.

14. Enraf-Nonius Structure Determination Package, Delft, The Netherlands, 1985.

15. Sheldrix, G. M. Acta Crystallogr., Sect. A 46 (1990) 467.

16. Willinski, J. and Kurland, R. J. Inorg. Chem. 12 (1973) 2202.

17. Kofod, P., Larsen, E., Petersen, C. H. and Springborg, J. Acta Chem. Scand. 46 (1992) 1149.

18. Goodfellow, R. J. In: Mason, J., Ed., Multinuclear NMR, Plenum Press, New York 1987, Chap. 20.

19. Hammershoi, A., Larsen, E. and Larsen, S. Acta Chem. Scand., Ser. A 32 (1978) 501.

20. Andersen, P. Acta Chem. Scand. 21 (1967) 243.

Received July 11, 1993. 